\title{
Political Economy Origins of
}

\section{Financial Markets in Europe And AsiA*}

\author{
Svetlana Andrianova, ${ }^{\dagger}$ Panicos Demetriades, ${ }^{\ddagger}$ and Chenggang $X u^{\S}$
}

This version: January 7, 2008

\begin{abstract}
This paper contributes to the finance-growth literature by examining the political economy origins of some of the most successful financial markets in Europe and Asia. It provides historical evidence from London, Amsterdam and Hong Kong that highlights the essential role played by the government sector in kick-starting financial development. We show that the emergence of financial systems did not occur through laissez-faire approaches and that secure property rights alone were not sufficient for financial development. In the cases of London and Amsterdam, governments created large trade monopolies which were responsible for all the major financial innovations of the time. In the case of Hong Kong, where the financial development model was bank-based, large banking monopolies with close links to the state were created. We argue, the three examples are not special cases and the role of government in the early stages of financial development has been widespread world-wide.
\end{abstract}

KEYWORDS: Monopoly, politics, institutions, finance

JEL: G18, N20, O16

\footnotetext{
*We acknowledge financial support from the ESRC under the World Economy and Finance Research Programme (Award reference RES-156-25-0009). We have benefited from helpful discussions with historians Huw Bowen and Anne Murphy, and also comments by Stjin Claessens and Steve Haber.

${ }^{\dagger}$ Department of Economics, University of Leicester, University Road, Leicester, LE1 7RH, United Kingdom. Email: s.andrianova@le.ac.uk.

${ }^{\ddagger}$ Department of Economics, University of Leicester, University Road, Leicester LE1 7RH, United Kingdom. Email: pd28@le.ac.uk.

${ }^{\S}$ Department of Economics, LSE, United Kingdom. Email: c.xu@lse.ac.uk
} 


\section{Introduction}

A broad consensus has emerged in the finance-growth literature suggesting that well functioning banking systems and capital markets help to enhance long-run growth. ${ }^{1}$ Moreover, the positive causal impact of finance on growth appears to have been present from the earliest stages of financial development in the Netherlands, England, United States and Japan (Rousseau 2002). This literature is, therefore, increasingly shifting its focus towards understanding the mechanisms that promote financial development. Recent contributions suggest that political economy factors, such as the role of industrial and financial incumbents, may hold the key to successful financial development. Rajan and Zingales (2003), for example, suggest that trade and financial openness, which curtail the power of incumbents and change their incentives, may be a useful mechanism of financial development. Acemoglu, Johnson and Robinson (2005a) sketch a dynamic political economy framework in which economic institutions that facilitate economic development are social decisions chosen for their consequences by the interaction between powerful political and economic forces. These authors strongly emphasize the role of broad based property rights protection for economic development in general and the development of financial markets in particular. Much of this literature utilizes a variety of stylised facts or historical examples, mainly drawn from the colonial period, which are primarily aimed at explaining the factors that explain institutional development in the 'colonies'. With one important exception (Acemoglu, Johnson and Robinson 2005b) there has been little attempt to gain an understanding of the factors that explain successful financial development in the colonizing powers themselves.

This paper aims to contribute to the finance-growth literature by examining the political economy origins of some of the most successful financial markets in Europe and Asia, drawing on a variety of historical sources. Specifically, it provides historical evidence primarily from London, but also from Amsterdam and Hong Kong, that

\footnotetext{
${ }^{1}$ See Levine (2003) and Demetriades and Andrianova (2004) for recent surveys of this literature.
} 
highlights the essential role played by the government sector in kick-starting financial development. While there are important differences between these examples, we show that the emergence of financial systems did not occur through laissez-faire approaches and that secure property rights alone were not sufficient for financial development. In the cases of London and Amsterdam governments created large trade monopoliesthe English East India Company and its Dutch equivalent - which became the leading joint-stock companies and were responsible for all the important financial innovations of the time, including the emergence of trade in shares. In the case of Hong Kong, where the financial development model was bank-based, large banking monopolies with close links to the state were created (e.g. the Hongkong and Shanghai Banking Corporation). These were modelled on the Bank of England-itself a banking monopoly for fifty years with close links to government - which also became a template for the development of many other banking systems around the world (Goodhart 1988).

We argue that the three examples we provide in this paper are not special cases. The role of government in the early stages of financial development has been widespread world-wide, including the Italian city-states of Venice and Genoa, the United States, and, more recently, in the newly industrialized East Asian economies such as Japan, South Korea and Taiwan.

The idea that the government can play an important positive role in the financial system is of course not a new one, see for example Stiglitz (1993). What is new in our paper is that the emergence itself of successful financial systems owes a lot to the involvement of governments, an aspect that has been neglected by previous literature on finance and growth. We find support for our view in the writings of classical economists. Adam Smith has been widely quoted for emphasising the importance of protecting property rights. However, his other important point, often overlooked, was that the security of property rights alone is not sufficient for economic development. Instead he believed that there must be government involvement in business. He pointed out that "property and civil government very much depend on one an- 
other..." and "...the preservation of property and the inequality of possession first formed it, and the state of property must always vary with the form of government..." (Smith 1763). Specifically, Smith argued that the government should erect and maintain certain public works and certain public institutions, "which it can never be for the interest of any individual, or small number of individuals to maintain because the profit could never repay the expense to any individual or small number of individuals..." (Smith 1776, p. 688). Here, by 'public works' Smith refers to companies (or new property rights) created by Royal (and later parliamentary) charter.

This paper is organised as follows. Section 2 documents the emergence of London as a financial market, highlighting the role of politics, institutions and finance, which include the rise of the trading and banking monopolies with close links to government. Sections 3 and 4 analyse the cases of Amsterdam and Hong Kong, while Section 5 highlights other cases. Finally, Section 6 summarises and concludes.

\section{The Emergence of London as a Financial Market}

A variety of historical sources suggest that London's stock market emerged during the latter part of the 17th century and continued to develop during the early part of the 18th century. Drawing on these sources, this section documents (i) the emergence of trading in stocks; (ii) the institutional changes that, as has been previously argued, facilitated the development of the stock market, (iii) the improvement in public finances and its relationship to stock market development. In so doing, it identifies the key players in the private and public sectors in this process, namely the leading joint stock companies, the monarch and parliament. This examination reveals the following two inter-related political economy aspects, which played a critical role in the emergence of London as a major financial market:

- The monopoly rights granted by the public sector (initially by the monarch and subsequently by parliament) to all the leading joint stock companies. 
- The long-term loans provided by the leading joint stock companies to the public sector in exchange for their monopoly positions.

Additionally, our analysis also highlights the role of foreign trade in the process, in the light of the fact that all but one of the leading joint stock companies in that period were involved in trade with different parts of the world.

\subsection{The Emergence of Trading in Stocks: 1661-1703}

Even though the London Stock Exchange was formally established in 1773, there is evidence of stock transfers taking place as early as 1661 while the publication of security price movements began in $1681 .^{2}$ Scott (1912) - one of the most authoritative historical studies of the emergence of joint-stock companies in Britain and Ireland - provides, among other rich information, a useful list of tables described as "Statistics of the Chief Joint-Stock Companies if England, Scotland and Ireland to 1720". The data, which include capitalisation figures and other useful information on each company show that by far the largest joint stock company throughout the 17th century was the East India Company (EIC), founded in 1599 to carry out trade with the East Indies and incorporated by Royal Charter in 1600. The second largest joint-stock company up to 1694 was the Royal African Company (RAC), founded in 1662 to carry out trade with Africa (Scott 1912, p. 325). Table 1 summarises the available data for share transfers of these two companies alongside Hudson's Bay Company, which was the third largest foreign trade company and is considered by historians as representative of smaller joint-stock companies at the time. In 1694, the

\footnotetext{
${ }^{2}$ Neal (1990b) identifies Whiston's The Merchants Remembrancer of 4 July 1681 as the first printed evidence which documents that stock exchanges were taking place. This particular publication, which was a sheet listing current prices of goods on the London market, also included information on the prices of the shares of the East India Company (EIC) and the Royal African Company (RAC) in the form of symbols that suggested that the price of the former was at its highest ever while that of the latter was at its lowest. The first listing of actual stock prices was in the 3 January 1682 issue of the same publication.
} 
market valuation of these three companies was $£ 1,212,720$ (EIC), 1185,175 (RAC) and $£ 52,762$ (Hudson's Bay). ${ }^{3}$ All three companies had monopoly rights granted to

TABLE 1: Transfers of stock in the foreign trade joint-stock companies, 1661-1689

\begin{tabular}{|c|c|c|c|c|c|c|}
\hline \multirow[t]{3}{*}{$\underline{\text { Year }}$} & \multicolumn{2}{|c|}{$\underline{\text { East India Company }}$} & \multicolumn{2}{|c|}{$\underline{\text { Royal African Company }}$} & \multicolumn{2}{|c|}{$\underline{\text { Hudson's Bay Company }}$} \\
\hline & Average & Total & Average & Total & Average & Total \\
\hline & $\begin{array}{l}\text { Number of } \\
\text { Transactions }\end{array}$ & Value & $\begin{array}{l}\text { Number of } \\
\text { Transactions }\end{array}$ & Value & $\begin{array}{c}\text { Number of } \\
\text { Transactions }\end{array}$ & Value \\
\hline $1661-63$ & 44 & 18,900 & - & - & - & - \\
\hline $1664-66$ & 57 & 23,900 & - & - & - & - \\
\hline $1667-69$ & 71 & 32,100 & - & - & - & - \\
\hline $1670-72$ & 126 & 47,000 & 49 & 19,500 & - & - \\
\hline $1673-75$ & 152 & 53,800 & 39 & 50,200 & 7 & 5,150 \\
\hline $1676-78$ & 131 & 55,400 & 42 & 48,670 & 6 & 5,450 \\
\hline $1679-81$ & 172 & 68,100 & 40 & 41,200 & 10 & 12,550 \\
\hline $1682-84$ & 780 & 268,300 & 67 & 49,160 & 29 & 13,650 \\
\hline $1685-87$ & 537 & 191,000 & 77 & 48,650 & 22 & 8,850 \\
\hline $1688-89$ & 655 & 238,000 & 91 & 46,800 & 24 & 5,390 \\
\hline
\end{tabular}

Source: Carruthers (1996, Table 7.1, p. 167) and Carlos, Key and Dupree (1998, p. 326, p. 337)

them by the monarch in their charter. The EIC was granted monopoly rights over all English trade to the east of the Cape of Good Hope. The RAC was given monopoly rights over all English trade from Sallee to the Cape of Good Hope. Hudson's Bay Company, incorporated in 1670, had a monopoly over trade in the region watered by streams flowing into Hudson Bay in Canada.

The stock exchange was highly localised, with the trades and the circulation of information about the current share prices and profitability prospects for joint stock companies taking place in the coffee houses of Exchange Alley. Table 1 shows that a market for EIC shares existed as early as 1661, while trade in the shares of the other two companies emerged in the 1670s, soon after their establishment.

\footnotetext{
${ }^{3} \operatorname{Scott}(1912$, Vol. I, p. 325).
} 
In 1694 the Bank of England (BoE) was established by parliamentary statute which provided it with a monopoly right to issue paper money and to take deposits. With an initial capital of $£ 1.2$ million, BoE overtook RAC as the second largest jointstock company. By the end of 1695 there were in excess of 140 joint stock companies with a total market capitalisation of $£ 4.25$ million. ${ }^{4} 50.3 \%$ of stock market capitalisation or $£ 2.14$ million was accounted for by three foreign-trading companies (EIC, RAC and Hudson's Bay). The BoE's capitalisation was $£ 0.72$ million or $16.9 \%$ of total market capitalisation. Thus, between them these four monopolists accounted for more than two thirds of stock market capitalisation, while other chartered companies (also monopolies in their spheres of activity) accounted for $10.0 \%$ of the market. Monopolies, therefore, accounted for more than three quarters of the capitalisation of the emerging stock market.

By 1703 total stock market capitalisation had reached $£ 8.5$ million. By that time the East India Company had been absorbed by the New East India Company (NEIC), which was initially set up to rival the old EIC. ${ }^{5}$ The combined stock of the two companies accounted for $26.6 \%$ of total market capitalisation. The second and third largest joint stock companies were BoE, which accounted for $21.2 \%$ of the market, and RAC which accounted for 13\%. Thus, even by 1703 the three largest monopolies accounted for over $60 \%$ of stock market capitalisation.

Smith (1929) quotes historical documents which provide evidence that a specialised class of stock brokers was developing in the latter part of the 17th century;

\footnotetext{
${ }^{4}$ See Scott (1912, Vol. I, p. 336). Although it is known that 150 joint-stock companies were in existence by the end of 1695 , due to fragmentary information for some of these companies it is possible to estimate total market capitalisation for only 140 of these.

${ }^{5}$ Even though The New East India Company was initially set up to compete with the 'old' East India Company, and succeeded in being granted monopoly rights over the trading route to India by parliament, the two companies traded in parallel for a short period and eventually merged in 1702 . During their co-existence trade with India was managed by a joint committee, i.e. it appears that they acted jointly as a monopolist (Scott 1912, Vol. III, p. 479).
} 
a regular tariff for dealing in securities seems to have existed certainly by 1694 . The activities of the brokers and the growth of speculation attracted the attention of the government. In 1697 there was the first attempt to regulate the activities of stock brokers through legislation that took the form of "An Act to restrain the numbers and ill-practices of stock-jobbers". The Act limited the number of brokers to 100 and provided for licensing arrangements by the lord mayor of London. Thus, historical sources confirm that organised, albeit unregulated, trading in stocks existed as early as 1661 and that by the end of the end of the 17th century trading became regulated. Moreover, it appears that monopoly was the modus operandi for all the leading joint-stock companies at the time.

\subsection{Politics, Institutions and Finance}

The emergence and steady expansion of the stock market in the 1670s and 1680s in London, as discussed above, prompts the question: What were the factors that brought about the market emergence? A well-established explanation of the development of financial markets in England, due to North and Weingast (1989), highlights the credibility of secure property rights, following the Glorious Revolution of 1688 when constitutional changes substantially shifted the power in favour of parliament and away from the monarch. ${ }^{6}$ In England under the Stuarts, the monarch was expected to fund the government ("live of his own") and had considerable discretionary power, largely unchecked by Parliament, to obtain funds for the Crown. As England was embroiled in the wars of the late 16th (the war with Spain in 1588, with its lasting debt legacy well after Elisabeth's death) and the first half of the 17th centuries, the legacy of financing the war effort left a chronic gap between the Crown's revenue and expenditure and was forcing the monarchy to search for ever-inventive ways of

\footnotetext{
${ }^{6}$ For a detailed historical account of political and economic realities of the 17th century England see Smith (1984) and Holmes (1993). A compact but highly informative account can also be found in Roseveare (1991).
} 
obtaining revenue: the sale of Crown's lands, hereditary titles, and monopoly licenses, as well as forcing loans on favourable terms for the Crown which in many instances were only partially repaid. These measures, coupled with the unique position of the monarch as the ultimate enforcer of the law, created a permanent tension between the Crown and wealth holders many of whom were members of Parliament.

The gradual erosion of the monarch's credibility to honour loan obligations throughout the first part of the 17th century reached its logical end in January 1672, when Charles II, unable to obtain further loans, had to resort to the temporary suspension of all loan repayments (known as the Stop of the Exchequer). The tension between the Crown and the Parliament was eventually resolved in 1688 when the two main English factions (Tories, the landed elite, and Whigs, the monied interests), who were alienated by the reigning King James II (the successor of Charles II), invited Mary and William of Orange to seize the throne in exchange for important constitutional concessions. This event became known as the Glorious Revolution of 1688, and its role in making England into the Great Power of the 18th century is well-documented by historians. The key of this momentous historical event was the monarchs' acceptance to respect Parliament and Parliament's laws: constitutional constraints were solidified in 1689 when the English Bill of Rights, the Toleration Act and the Mutiny Act were passed, while the fiscal constraints on the crown were firmly established by 1697 with Parliament given the power to authorise taxation and audit revenues.

There is consensus in the literature (see North and Weingast (1989) and Dickson (1967), among others) that the Glorious Revolution led to a substantial improvement in public finances by removing the possibility of default by the monarch/government witnessed before $1688 .^{7}$ Parliament gained the power to scrutinise all government

\footnotetext{
${ }^{7}$ Note, however, that Roseveare (1991) strongly argues that the two decades before the Glorious Revolution constitutional, administrative and financial innovations paved the way for subsequent developments in public finance and institutional changes of the 1690s: "The philosophy of accountability which was to shape post-Revolution financial control [on government spending] was clearly articulated in the reign of Charles II" (p. 15, bottom).
} 
accounts, which severely limited the ability of the monarch to over-spend. Moreover, increased accountability resulted in certain taxes being earmarked for meeting public debt obligations, which made the commitment to repay debt credible.

It has also been argued by North and Weingast (1989) that these institutional reforms were a legal milestone for the development of private capital markets, essentially by strengthening the security of property rights. However, this is a controversial interpretation of these reforms. Undoubtedly, to the extent that the reforms following 1688 enhanced the security of property rights, they must have also strengthened investors' confidence and (together with other characteristics of the early 18th century economic and political life in England) contributed to the growth of financial markets. However, the active exchange of company shares, documented in Section 2.1, was taking place well before the Glorious Revolution. The increasing trend in the transfers of company shares over 1660-1688 (see Table 1) suggests that investors felt sufficiently secure to be willing to undertake the trades. Hence the emergence and expansion of the stock market in Exchange Alley in the 1670s and 1680s calls for a different explanation.

The North and Weingast interpretation of the implications of 1688 for private capital markets has also been questioned by economic historians, political scientists and sociologists. Stasavage (2002), for example, suggests that the multiple veto points introduced by the reforms were neither necessary nor sufficient for the credibility of commitment and that partisan politics played a much more important role. Critique by Carruthers (1996) emphasises the importance of the joint-stock companies for public finance. Carlos et al. (1998) suggest that “... it is necessary to question the implicit, if not explicit, assumption that the London capital market emerged Phoenixlike from the ashes of the old regime" (p. 319). Their examination of the early market for stock of the Royal African and Hudson's Bay companies highlights the importance of the micro-institutional structure of financial markets, including investor's learning about financial risk and rewards, the gathering of information about companies, how to buy and sell securities, where to buy and sell etc. They conclude that even financial 
regulation had its roots in investor's learning: "this learning must also have provided the experience that allowed investors to deal with various financial crises in terms of regulation rather than market rejection" (p. 343).

\subsection{The Improvement in Public Finances}

Up to 1688 , crown borrowing was short-term and was mainly carried out through goldsmith bankers. ${ }^{8}$ Government debt amounted to no more than $£ 1$ million, which severely constrained government spending. ${ }^{9}$ There was a chronic gap between government revenues and government expenditure which hindered the ability of the monarch to sustain a strong army. ${ }^{10}$ As a result England was weak as a military power. From the 1690s onwards the volume of government long-term borrowing expanded very substantially, resulting in government debt rising from $£ 1$ million in 1688 to $£ 16.7$ million by $1697 .^{11}$ Table 2 , which portrays the sources of government long-term borrowing during 1693-1698, shows that this period witnessed a remarkable increase in the ability of the government to raise long-term loans.

Interestingly, the largest two loans raised by the government during this period were from the New East India Company (NEIC) and the Bank of England, amounting to $£ 2.0$ million and $£ 1.2$ million, respectively. These loans were provided at the same time the two companies were incorporated by parliamentary statute. This was not a coincidence. In the case of the NEIC Scott (1912) states that "The original capital consisted of 1,662,000 lent to the government, out of a total of 2,000,000, which carried the monopoly of the trade to India" (p. 479). There is, therefore, clear evidence that the loan to government was granted by the NEIC in a direct exchange

\footnotetext{
${ }^{8}$ Forced loans from wealthy corporate bodies such as EIC or the Corporation the City of London were also important sources of funds for the Crown (Roseveare 1991, p. 23).

${ }^{9}$ North and Weingast (1989, Table 3, p. 822).

${ }^{10}$ Carruthers (1996, Ch. 3).

${ }^{11}$ North and Weingast (1989, Table 3, p. 822).
} 
TABLE 2: Sources of government long-term borrowing, 1693-1698

\begin{tabular}{rccl}
\hline $\begin{array}{c}\text { Date of } \\
\text { royal assent } \\
\text { to Loan Act }\end{array}$ & Sum raised & Interest, $\%$ & Type of fund \\
\hline 26 Jan 1693 & $£ 108,100$ & 10 until & Tontine \\
& & mid-1700, & \\
& & then 7 & \\
26 Jan 1693 & $£ 773,394$ & 14 & Single life annuities \\
8 Feb 1693 & $£ 118,506$ & 14 & Single life annuities \\
23 Mar 1694 & $£ 1,000,000$ & 14 & Million Lottery \\
24 Apr 1694 & $£ 1,200,000$ & 8 & Bank of England \\
24 Apr 1694 & $£ 300,000$ & 10,12, and 14 & Annuities for 1, 2, and 3 lives \\
16 Apr 1697 & $£ 1,400,000^{*}$ & 6.3 & Malt Lottery \\
5 Jul 1698 & $£ 2,000,000$ & 8 & New East India Company \\
\hline
\end{tabular}

\footnotetext{
* This was a lottery of $140,000 £ 10$ tickets; only 1,763 tickets were in fact sold. The rest were used by the Exchequer as cash. Source: Dickson (1967, pp. 48-9)
}

for the monopoly rights over the trading route to India.

In a similar vein, the Bank of England provided the whole of its initial capital of $£ 1.2$ million as a long-term loan to the government directly in exchange for its monopoly license. Scott (1912) describes the bargaining between parliament, which was trying to raise funds for the war with France (the war of Spanish succession), and the two major syndicates with different political affiliations that were bidding to secure the monopoly right of circulating paper money during 1692-1693. One of these was led by Chamberlain, who was affiliated to the Tories (who then represented the interests of landowners). The other syndicate, led by Paterson, who was affiliated to the Whigs (otherwise known as the 'moneyed men'), was the one that succeeded through a revised proposal which provided a loan to the government of $£ 1.2$ million 
at $8 \% .{ }^{12,13}$ Historical sources therefore suggest that parliament actively encouraged bids for the granting of valuable monopoly 'licenses' to joint stock companies led by individuals with political connections.

The loans provided by the NEIC and the Bank of England to the government were perhaps the largest at the time but were by no means exceptional. They were very much the normal way in which the business of public finance was conducted in those days. Carruthers (1996, p. 76) aptly summarises the relationship between the joint stock companies and the government in the 1690s:

"Joint stock companies enjoyed special privileges and monopoly power granted by the state and in exchange for this they customarily made a financial contribution. What distinguished this period from earlier ones was the sheer volume of borrowing from companies, and the fact that company shares could be easily traded on the London stock market. In contrast with annuities and lottery loans [the other two prominent methods of government borrowing at the time], and unlike shares in earlier times, by the late seventeenth century company equity was easily transferable to third parties. Through joint-stock companies, public finance became linked to private finance and to the London stock market."

It can therefore be concluded that the emergence of London's stock market undoubtedly contributed to the improvement in public finances. It may also be argued that granting monopoly licenses to the companies that provided loans to the government made these companies more profitable, which in turn made it easier for them to raise capital. Thus, the development of the stock market went hand in hand with the improvement in public finances.

\footnotetext{
${ }^{12}$ The capital was raised through subscriptions that were limited to $£ 10,000$ per person; the subscription lists opened on 21 June 1694 offered a discount to early subscribers; the issue was sold by 2 July 1694 .

${ }^{13}$ Interestingly, this loan was never repaid (Carruthers 1996, p. 80).
} 


\subsection{Trade and Growth}

A variety of sources suggest that the period after 1660 was characterised by an expansion in trade and a rise in real incomes. Holmes (1993) describes the period between the late 1660s and 1690 as the English 'Commercial Revolution', which was characterised by an acceleration of trends already in evidence before 1660. He ascribes the acceleration in trade in large part to government measures such as the new navigation policy, legislation that was highly protective of English shipping. ${ }^{14}$ Contributing factors were also the acquisition of the Carolinas and the further development of existing colonies. An outstanding feature of the commercial revolution was the expansion of trade beyond Europe, particularly 'the plantations' in North America and the West Indies in the west and India in the east, through the EIC trading posts. Holmes (1993) suggests that the total tonnage of English merchant shipping increased from 162,000 tons in 1629 to 340,000 tones in $1686 .^{15}$

Estimates of trade statistics by Davis (1954) show that total exports increased from 4.1 million in 1663-69 to 6.4 million in 1699-1701, representing an increase of over $50 \%$, while total imports increased from $4.4 \mathrm{~m}$ to $5.8 \mathrm{~m}$ during the same period.

\subsection{The Role of Monopolies}

The large monopolies appear to have been efficient forms of organising overseas trade (in the case of EIC, RAC and Hudson's Bay) and banking activities (in the case of the BoE). The companies evidently enjoyed economies of both scale and scope. In the case of the trading monopolies, there were operational economies of scale largely due to security considerations which, among other things, dictated creating

\footnotetext{
${ }^{14}$ The 1660 Act for encouraging and increasing of shipping and navigation was aimed at breaking Dutch dominance and boosting the merchant fleet by introducing selective prohibitions or deterrents in using 'foreign' ships e.g. double custom duties on imports if not transported in English-owned or manned ships, prohibition of using 'foreign' ships in all trade with the 'plantations'.

${ }^{15}$ See also Carruthers (1996, Ch. 5, fn. 1).
} 
and maintaining a private army, a right stipulated in their charter of incorporation. ${ }^{16}$ The state was reluctant to offer protection to these companies in overseas territories because it wanted to avoid unnecessary wars. ${ }^{17}$

The trading technology itself exhibited economies of both scale and scope in that there were large set up costs in establishing trading outposts along a particular trading route, which however facilitated the expansion of trade into neighbouring regions. ${ }^{18}$ In addition, the large size of these monopolies, particularly the EIC, created financial efficiencies that were responsible for financial innovations that arguably were responsible for the emergence of the financial market. In the early years of the EIC (up to the 1650s), the company raised capital for each voyage, at the end of which the investment was liquidated and profits, if any, distributed to investors (Scott 1912, Vol. II). Thus, investment was highly risky. From the 1660s, the company started issuing permanent capital, leading to the emergence and expansion of trade in shares. ${ }^{19}$ This innovation resulted in much lower risk for investors who benefited from the diversification offered by multiple voyages, thereby providing an important stimulus for savings mobilisation. The subsequent emergence of trading in stocks triggered another financial innovation which involved a simplified procedure for transferring the

\footnotetext{
${ }^{16}$ Scott (1912, Vol. I, p. 179) documenting the public debate on monopolies in the late 1600s and early 1700s notes that "Companies for foreign trade were generally admitted to require extensive immunities, since they performed functions which the State was not able to undertake".

${ }^{17}$ See Scott (1912, Vol. I, p. 253) for a discussion of the importance of foreign trade joint-stock companies being able to defend themselves: without a private army the company would need to call upon the state to defend the trading route against foreign competitors and pirates thus drawing the country into a war with another, without any other good reason for such war.

${ }^{18}$ See, for example, Scott (1912, Vol. II, pp. 21-22) for an illustration of the costs involved in the case of the Royal African Company.

${ }^{19}$ Upon the renewal of the EIC's charter in 1657, a provision was made to issue capital which were to be permanent for 7 years. At the end of this period, in October 1664, it was announced that "the whole gain for the seven years may be taken at 90 per cent or an annual average of about 13 per cent", which signified the fact that the transition from terminable to permanent capital was complete (Scott 1912, Vol. II, p. 129, 132).
} 
ownership of shares (ibid.).

It is hard to see how these critical financial innovations could have been delivered by smaller foreign trading companies, in competition with each other. ${ }^{20}$ It would have been too expensive for each of them to set up and maintain a private army. Without this protection, the voyages of these companies would have been much riskier than the voyages of the EIC. Thus, savings mobilisation by smaller companies would have been much more problematic. Raising permanent capital would have also been problematic without the diversification offered by a large number of voyages.

There were also economies of scale and scope in banking activities. Note issue technology exhibits economies of scale due to large fixed costs emanating from, for example, the need to prevent forgery. Deposit taking typically facilitates making loans and vice versa. Providing banking services to the state may also involve such economies. However, these economies quickly disappear when the market becomes sufficiently large. This suggests that the market for banking services may exhibit features of a natural monopoly in the very early stages of banking development but more than one bank may operate efficiently once the market reaches a certain size. This may well explain why the BoE lost its monopoly status after fifty years of operation as a result of competitive pressures.

Even though monopolies were efficient forms of organisation at the time, they did not result in the creation of economic oligarchies because their ownership was broad-based. This also meant that they could mobilise saving by raising capital from a large number of investors. Table 3 shows the number of shareholders in the leading joint-stock companies during 1601-1720. The number of shareholders in the EIC grew from about 200 at its foundation to 1,200 by the end of the 17 th century. The Bank of England had more than 1,200 shareholders when it was founded in 1694. Even the Hudson's Bay Company, the capitalisation of which was less than $5 \%$ of the EIC, had

\footnotetext{
${ }^{20} \mathrm{~A}$ case in point is the formation of the Dutch East India company through the amalgamation of several competing companies which resulted in the creation of a private army (see Section 3 ).
} 
as many as 89 shareholders by 1720 .

TABLE 3: Number of shareholders in leading joint-stock companies

\begin{tabular}{ccccc}
\hline Year & EIC & $R A C$ & $H B$ & BoE \\
\hline 1601 & 198 & - & - & - \\
$1617-1628$ & 954 & - & - & - \\
1670 & - & - & 18 & - \\
1672 & - & - & 32 & - \\
1680 & - & 186 & - & - \\
1681 & $530-600$ & - & - & - \\
1688 & 320 & - & - & - \\
1693 & 482 & - & - & - \\
1694 & - & - & - & 1,267 \\
1698 & 1,200 & - & - & - \\
1701 & 763 & - & - & - \\
1702 & 759 & - & - & - \\
1703 & 960 & - & - & - \\
1707 & 916 & - & - & - \\
1708 & 965 & - & - & - \\
1720 & - & - & 89 & - \\
\hline & & & & - \\
\hline
\end{tabular}

Source: Scott (1912, Vol. III, pp. 464-7, 472-3, 476-7).

The granting of monopoly rights to joint-stock companies was not uncontroversial. Nevertheless, it was felt that on balance these monopolies were beneficial forms of organisation. A prominent statesman of the time, Sir Robert Walpole (a Whig, First Lord of the Treasury, and the leader of the Cabinet over 1730-1742), joining the debate on the detriments of monopoly in usual economic activity, notably supported monopoly in foreign trade and banking when he stated in 1737 : 
"...though in most sorts of trade, an exclusive privilege may be of bad consequence, I am nevertheless of opinion, that with respect to the Banking trade, and the trade to the East-Indies, neither the one nor the other can be carried on with such success, or in such an extensive manner, by private adventurers, as by a public company with such an exclusive privilege as our present companies have; and in this opinion I am supported by the example of our neighbours the Dutch, who, I believe, understand trade as well as most of their neighbours." (Parl. Hist. x.54, II March 1737, cit. op. Dickson (1967).)

\subsection{Summary}

The emergence of London's stock market in the period 1661-1703 is clearly associated with the emergence and establishment of large trading companies which enjoyed monopoly rights over their trading routes such as the EIC and RAC. The monopoly rights which these companies enjoyed contributed to their profitability, which made their shares highly liquid. These developments facilitated the mobilisation of savings and therefore contributed to the growth of stock market capitalisation while their success inspired the establishment of new companies. It is therefore clear that the granting of monopoly rights initially by the monarch and subsequently by parliament played a critical role in the emergence of the London stock market and its subsequent development.

Trading in the stocks of these companies emerged well before 1688 suggesting that private property rights were sufficiently secure before the Glorious Revolution. The Glorious Revolution of 1688 was clearly a legal milestone for the improvement in public finances, which became evident after 1688. Lending to government became more secure after 1688, which may have had an indirect influence on the development of the stock market. Specifically, the government was able to raise long term loans from joint stock companies in exchange for the granting (or renewing) of monopoly licenses. Both the NEIC and the BoE loans were cases in point. To the extent that 
the monopoly licenses made these companies more profitable, it can also be argued that the need to improve public finances contributed to the further development of the stock market.

There is therefore little doubt that the emergence of London's financial market was far from spontaneous, owing much to the interplay between politics and economics, which resulted in the formation of large trade monopolies with close links to government. While various kings received "forced" loans and "gift" loans in return for granting monopoly rights to EIC and RAC during the early part of the 17th century (Scott 1912, Vol. II), it appears that by the end of the same century its benefits for public finances were well understood by parliament. What can also be concluded from our analysis is that the much discussed influence of the institutional reforms of 1688 on the development of the stock market was, at best, an indirect one.

The same monopoly companies that accounted for the emergence of London as a financial market can also be credited for the improvement in public finances, as well as the expansion of trade. The rise in real incomes which followed the expansion of trade created additional wealth, setting in motion a virtuous finance-trade-growth cycle which transformed England from a weak state in the early part of the 17th century to Europe's foremost military power by the beginning of the 18th century.

\section{Amsterdam}

A pre-cursor of the London stock market, the Amsterdam stock exchange, from its establishment dominated by trade in the shares of the Dutch East India Company, can be seen as the end-product of a natural experiment progressing along quite dissimilar lines, when compared to London, yet producing a remarkably similar relationship between the state, the foreign trading monopoly and the emergence of the stock market.

The Dutch example differs from the English one in several important respects. 
In the historical period of interest, the Netherlands, or more precisely the United Provinces, represented the only federal state in Europe. The strength of Amsterdam in the late 1500s as a centre of commercial activity, the trading entrepôt of Europe with its massive commodity warehouses, sophisticated credit techniques, and emergence of speculative financial activity, is well-documented (Barbour 1950, Israel 1989, de Vries and van der Woude 1997). The Dutch actively began exploring the trading route to the East Indies in the 1590s, successfully checking the Portuguese supremacy and making this route consistently important for the United Provinces from then on (Israel 1989). Noteworthy, there was a number of Dutch enterprises established in the period of 1594-1599 for the sole purpose of trading with the East Indies: starting with the Compagnie van Verre at Amsterdam in 1594, and quickly followed by two more East India companies at Rotterdam in 1598, and a second company at Amsterdam in 1599. High profits of these early companies in 1598-9 stimulated proliferation of new companies in Amsterdam, Rotterdam, Zeeland, and the North Quarter, based at Hoorn and Enkhuizen, and with investment being drawn from inland towns such as Delft and Dordrecht. The ensued competition between rival companies, however, was beginning to affect profits by 1601 so much so that the merchants and burgomasters of the towns felt "it was getting out of hand": in the six years to 1601 the price of pepper paid by the Dutch merchants in Indonesia rose by 100 per cent, while at home the stock piles of pepper and fine spices led to the inevitable drop in the price charged to the consumer (Israel 1989). The merchants therefore persuaded the head of the Dutch government (Johan van Oldenbarnevelt, Advocate of the States of Holland) to consolidate the trade in one company. However, given the federal structure of the republic and the geographical spread of investment capital, the intricate detail of the new organization took months of intense negotiation between Oldenbarnevelt and the directors of the independent companies. The United Dutch East India Company (Verenigde Oostindische Compagnie, or VOC) was eventually issued its charter (octrooi) by the States General in early 1602 to enjoy monopoly of all Dutch trade east of the Cape of Good Hope. Noteworthy, the charter 
bestowed upon the VOC not just vast commercial privileges, but also extensive military and political powers (such as deploying armies and navies in Asia in the name of the States General and conducting diplomacy under the States General flag and seal). ${ }^{21}$ It is also important to note that the company was subject to supervision, and its charter to periodic renewal, by the States General. ${ }^{22}$ In fact, the amalgamation of individual companies was as much an economic act as it was a political act, since the managerial group of the united company had close affiliation and unity of interests with the political authorities (Steensgaard 1982). The historical sources, therefore, strongly suggest that "the VOC was the creation of the Dutch state, as much as of the merchants who had actually opened up the East India traffic" (Israel 1989, p. 72). ${ }^{23}$ The perception of the VOC as the extension of the state in the farflung territories of Asia, in fact, led to some discontent among investors who felt that "the profit was being sacrificed to the political objectives of the Dutch state" (Israel 1989, p. 72), with substantial amounts of the company funds being spent on arms,

${ }^{21}$ In 1751, a century and a half later, commenting on the might of the VOC at the zenith of its economic and political power, Malachy Postlethwayt asserted in the Universal Dictionary: "one of the reasons why the Dutch East India company flourishes, and is become the richest and most powerful of all others we know of, is its being absolute, and invested with a kind of sovereignty and dominion, ...[it] makes peace and war at pleasure, and by its own authority; administers justice to all; ... settles colonies, builds fortifications, levies troops, maintains numerous armies and garrisons, fits out fleets, and coins money". Cit. op. Neal (1990a, p. 196).

${ }^{22}$ Israel (1989, p. 71) documents that "the charter stressed that the VOC's purpose was not just to enable all subjects of 'these United Provinces' to invest in the East India traffic, but also to attack the power, prestige, and revenues of Spain and Portugal in Asia".

${ }^{23}$ A distinguished historian of the Dutch East India Company, Niels Steensgaard suggests that "The VOC integrated the functions of a sovereign power with the functions of a business partnership. Political decisions and business decisions were made within the same hierarchy of company managers and officials, and failure or success was always in the last instance measured in terms of profit. By these means the company as a business venture was able to internalise protection costs, and protection costs were added to overheads that might be calculated rationally" (Steensgaard 1982, p. 237). 
munitions, troops and fortifications. ${ }^{24}$ Still, as the arm of the state, the VOC proved astoundingly successful within a short space of time, achieving global supremacy in the spice trade by 1605.

Importantly for our argument, the emergence of the stock market in Amsterdam is firmly linked to the establishment of the VOC. As de Vries and van der Woude (1997, p. 385) suggest, in the early years of the VOC operations an important principle was established that the capital invested in the company would be permanent and any investor wishing to liquidate their interest in the VOC could sell their share to a buyer on a stock exchange (Beurs), thus linking the birth of the Amsterdam stock market to trade in the VOC shares. By 1608, the method of selling and buying VOC stock, as well as forward share selling, was well established (Dehing and 't Hart 1997). Moreover, using company records, notarial deeds, government ordinances and the business papers of an Amsterdam merchant, a recent article by Gelderblom and Jonker (2004) reconstructs the finance of Dutch East India trade in 1595-1612, to demonstrate that shortly after the VOC was chartered in 1602, a vigorous secondary market in VOC shares emerged in Amsterdam, complete with extensive speculative activity and the first bear raid in 1609-10. Gelderblom and Jonker (2004, p. 654) also find that the establishment of the VOC had a consequence of spreading the shareownership much wider than was previously observed. "The Amsterdam chamber [of the $\mathrm{VOC}]$ had more than 1,100 initial subscribers on an estimated adult population of no more than 50,000 people. The huge profits of some Asian expeditions had created a keen public interest, to the point of attracting even small savers investing up to 150 guilders."

In conclusion, what this example illustrates is that the way the monopoly was obtained (be it by the Royal Charter granted by a monarch in England or the charter drawn up following fierce negotiations between the merchants and political elite of the independent federal states in the United Provinces) was not as important as the

\footnotetext{
${ }^{24} \mathrm{~A}$ more detailed picture could be seen in Steensgaard (1982, p. 247).
} 
purpose it was assigned by the state: to consolidate the trading profits which could then be relied upon in the state of either peace or war, and which at any rate the government could tap in for the purpose of state- and empire-building. The trading monopoly in both London and Amsterdam was the vital ingredient in generating substantial resources for the government at the early stages of financial development. The substantial resources were creating the virtuous cycle of growth and development: greater resources allowed the monopoly to fortify its operations and reap greater profits, which made the trading in company shares increasingly more desirable; the increasing profitability of shares led to increased volume and innovation in share trading and that fostered stock market emergence and expansion.

\section{Hong Kong}

The financial development in Hong Kong in the 19th century, in contrast to that of England or the United Provinces of the 17th century, was bank-based, rather than stock-market-based. Nevertheless, a similar pattern of a monopoly actively supported by the government as the key ingredient of the emergence and expansion of finance is confirmed by historical sources (King 1983, King 1987, Ji 2003). The monopoly that played a special role in the financial development of Hong Kong was the Hongkong and Shanghai Banking Corporation, often referred to as the Hongkong Bank in historical sources, or, as we know it today, HSBC. At present, HSBC is the largest bank in Hong Kong and the only bank established outside developed economies to become one of the largest banks worldwide. ${ }^{25}$ Despite being a British overseas bank, HSBC had been headquartered in Hong Kong (from its foundation until 1991), with 80 per cent of its earnings originating from outside Britain, and grew mainly in the Far East, not Britain.

\footnotetext{
${ }^{25}$ According to The Economist (6 July 2006), HSBC was the largest banking group in the world by tier-one capital as of end-2005.
} 
To place the foundation and operations of HSBC, or more appropriately, the Hongkong Bank, in historical perspective, it must be noted that the Hong Kong island emerged in 1841 as a free trading post of great economic significance, lying on the "cross-roads" of trading routes between Europe, China and Japan. Hong Kong became a British colony in 1842 under the Treaty of Nanking; it had no representative government (with the colonial governance being enacted by the Hong Kong Governor), neither did it have local currency. The Hongkong Bank was founded as a British overseas bank in 1865, initially as a limited company, by representatives of the major trading houses (hongs) on the China coast. ${ }^{26}$ The explicit objective of the founders was to set up a 'local' bank - local in a sense of an overseas regional bank, headquartered locally - that would cater for the needs of merchants involved in the growing trade between Europe and China. Thus, from its inception, the Hongkong Bank had a clear link to overseas trade. The historical sources also clearly identify the founding fathers' intent to achieve incorporation of the bank by a special dispensation from the British Treasury ${ }^{27}$ which, once obtained in 1866 , moulded the activities of the Hongkong Bank in the tradition of a royally chartered bank. ${ }^{28}$ The important privilege granted to the Hongkong Bank at its (re)incorporation in 1866 was the right to issue banknotes in Hong Kong and in South East Asia, while the significance of the special dispensation was in the assurance it provided that the notes

\footnotetext{
${ }^{26}$ In his authoritative four-volume history of HSBC, King (1987, Vol. I, p. 54) states that "The success of the Hongkong Bank undoubtedly rested from the first on the broad international base of its directorate. This was a British bank in a British colony on whose founding committee eight of the fourteen members were not from Britain."

${ }^{27}$ The special dispensation is known as the 'special Hong Kong ordinance' and it was drawn up to be consistent with the provisions of the Colonial Banking Regulations (King 1987, Vol. I, p. 110). The ordinance was for the term of 21 years, renewable on expiry.

${ }^{28}$ The alternative to the special ordinance at the time would have been to register the bank as a limited company, which in fact is exactly the organisational form that the Hongkong Bank adopted in the period 1865-66. However, the registration as limited company would have prevented the bank from enjoying important monopoly rights, discussed below, which were only attainable through incorporation by special ordinance.
} 
would be accepted by colonial government treasuries (e.g. in payment of government dues and taxes). The latter lent credibility of the note issue with the general public. Incorporation by the special ordinance, therefore, implied a kind of endorsement by the British government of the Hongkong Bank and of its notes, and that came at the price of the bank agreeing to provisions which ensured the public's ability to encash the bank's banknotes. ${ }^{29}$

In the 1860s, the Hongkong Bank was one of only two private banks enjoying the privilege of note issue in Hong Kong. ${ }^{30}$ However, an important monopoly right granted to the Hongkong Bank in 1872 by the Hong Kong Governor, hotly and unsuccessfully contested by its rivals, was issue of notes with denomination less than 5 dollars. Following the fiscal difficulties of the Hong Kong Mint which closed down (was sold to the Japanese) in 1866 after having existed for barely two years, this monopoly right was subsequently confirmed by the British Treasury, which at that time saw itself as the guardian of financial stability throughout the British Empire. Moreover, the Hong Kong Governor found legal solutions for the Hongkong Bank to expand its operation (including that of note issue) beyond the colony into South China, Singapore, Malaya and elsewhere, in effect permitting excessive profits to a privately owned institution (King 1983, p. 153).

Another important privilege enjoyed under the special ordinance of the Hongkong Bank was the ability of the bank to bid for government accounts. After a successful bid for the British Government 'Treasury Chest' and for the principal account of the Hong Kong Government in the 1870s, the Hongkong Bank became, in effect,

\footnotetext{
${ }^{29}$ The specific provisions under the special ordinance included the bank's shareholders bearing double liability (ie double of their capital invested in the bank) and shareholders' unlimited liability in relation to note issue. See King (1983, pp. 150-4) and King (1987, Vol. I) for further details.

${ }^{30}$ The other private bank was the Chartered Bank of India, Australia and China which was founded by Royal Charter in 1853 and allowed to issue banknotes in Hong Kong from 1862. Along with only two other private banks, HSBC has retained the privilege to issue banknotes to the present day, its banknotes becoming legal tender in 1935 .
} 
the banker to both the British Government and the local government. By 1895, the Hongkong Bank had become the virtually permanent banker to the British Government in China and was responsible for over 80 per cent of the local note issue (King 1987, Vol. II). From then on, the Hongkong Bank was called upon to provide banking services for the British armed forces and for the consular services. As experts and government bankers, its officers were also called to give advice on important economic and political decisions pertaining to the British financial interests in the East. The Hongkong Bank's direct involvement in assisting the British Government in political and economic negotiations with the Imperial Government of China was manifested in the bank's sponsorship of the founding of the British and Chinese Corporation, a company designed to bring together British China interests (King 1987).

Along with holding the British Government accounts, the Hongkong Bank succeeded in becoming the government's banker for the Chinese Imperial government or Qing government (before the 1911 revolution), dealing extensively in government loans for political indemnities, national railways and even military campaigns (Ji 2003). In 1870 it provided a loan of 4 million silver taels at 14 per cent interest to the Chinese government for its Northwest Campaigns. In the period between 1878 and 1890, the Chinese Imperial government contracted 26 foreign loans, of which 17 were provided by the Hongkong Bank. ${ }^{31}$ The bank's total loans over the period of 1874-1890 amounted to $28,970,000$ tael, or over 70 per cent of all foreign loans (Ji 2003). These loans provide additional evidence for the statement found in King (1987, Vol. I, p. 17) that the Hongkong Bank "regarded the Chinese authorities as a major constituent and was commercially interested in providing sound advice and in maintaining, sometimes at considerable expense, the credit-worthiness of the Chinese Government" [emphasis added].

It is, therefore, evident from the above, that during the first three decades of its operations, the Hongkong Bank evolved from having a status of 'local' bank to

\footnotetext{
${ }^{31}$ These included three major loans of 1,604,276 pounds at 8 per cent interest in $1877,1,949,500$ tael at 8 per cent interest in 1878 and 4,834,000 tael at 8 per cent interest in 1881 (Ji 2003).
} 
become by the end of the 19th century the most important foreign financial institution in the East. It acted as the government's banker to both the British and Chinese governments. It became the leading bank throughout East Asia, enjoying the privilege of note issue in Hong Kong, China, Thailand, Singapore and elsewhere. For more than half a century the financial markets of East Asia, including China, set their daily foreign exchange rate based on exchange rates set by the HSBC. As outlined above, from its very beginning the HSBC had the following features: (i) it enjoyed close support by the Hong Kong and British governments for its monopoly power; (ii) this monopoly power provided the HSBC with a huge influence far beyond Hong Kong; (iii) the bank was highly involved in financing international trade, particularly so when it was founded; (iv) the bank served for the British/Hong Kong government as a quasi-central bank; it was the most important bank which issued loans to the British/Hong Kong governments and the Chinese government. These features and the record of the bank's enormous success throughout its history provide support for our argument that a monopoly actively backed by the government was also the key ingredient of the emergence and expansion of banking in East Asia.

\section{$5 \quad$ Other examples}

\subsection{Italian city-states}

The successful examples of London and Amsterdam in Europe were pre-dated by those of the Italian cities during the Renaissance. Banking, trade and industry flourished during those times and government played a central role in these developments. Genoa and Venice were very important in Mediterranean trade, with the latter becoming the most prosperous; its merchants became the intermediaries between East and West, receiving trading privileges from the Byzantine and German emperors, and even the Mohammedans (Gilbert 1998). Numerous other cities grew and flourished, making Italy the most highly urbanized region in Western Europe in the 14th century. 
Political power within the Italian cities belonged to the possessors of urban wealth, i.e. the bankers, the merchants and the businessmen.

Fratianni and Spinelli (2005) argue that Genoa and Venice in the 15th and 16th centuries had developed many of the features of the 'financial revolutions' that were to be found much later on in the Netherlands, England and the United States. Specifically, these features include (i) credibility of debtor's promises; (ii) the role of national banks in facilitating the development of financial markets; (iii) the extent and depth of financial and monetary innovations. Fratiani and Spinelli show that both Genoa and Venice exhibited all three features, even though there were some important differences between the two.

Genoa and Venice had in place different commitment mechanisms that enabled them to issue long-term debt. Venice set aside specific tax revenues to service the public debt; while early period loans to the state were compulsory and based on income, they subsequently became voluntary. In Genoa, which was more politically divided than Venice, the commitment mechanism passed through the national bank (the Casa di San Giorgio), which was a semi-public institution with control over the tax revenues. San Giorgio represented the interests of the states creditors, but at the same time it was also concerned about the political and economic viability of the debtor. Neither Venice nor Genoa defaulted on their debt, even though Venice often delayed paying interest. Both Genoa and Venice - Genoa more than Venice-carried a low cost of public debt. Investors believed in the state honouring its promises and were willing to accept a lower return on invested funds.

Both Genoa and Venice had their own public banks. Venice had (i) the Banco di Rialto, which was a pure payment bank - the closest predecessor of the Wisselbank of Amsterdam - and (ii) the Banco Giro, which was an issue bank and the fiscal agent of the Republic of Venice: it was the closest predecessor to the Bank of England and the First Bank of the United States. ${ }^{32}$ Genoa had the San Giorgio, which was a

\footnotetext{
${ }^{32}$ The Wisselbank of Amsterdam was established in 1609 as a public deposit bank and economic
} 
predecessor of the Bank of England.

Finally, both Genoa and Venice, but especially the former were financial innovators. Genoas San Giorgio invented the debt-equity swap and both cities understood the relationship between reputation and cost of debt. In Genoa there was an active money market in which merchants used declared but not matured interest on government debt to settle due payments and to extend short-term credit.

\section{$5.2 \quad$ U.S. state banks}

Even in the United States the role of the government in the early stages of financial development was an important one. Sylla, Legler and Wallis (1987) outline the 'intimate' relationships which existed between state banks and state governments, whereby state-chartered banks became integral elements of public finances between 1790 and 1860. In several instances, such banks were either wholly owned or operated by state governments, but even when this was not the case, states purchased bank shares either when a bank was launched or at a later stage. This was very much a two-way relationship not unlike the relationships that were common during the emergence of London's financial system in that (state) governments, at the time of granting or renewing charters, were obliging state-chartered banks to pay lump sum bonuses to them. Sylla et al. (1987) find that about one fifth of state revenues during that period was derived from banks. ${ }^{33}$

\footnotetext{
historians are in virtual agreement that it was patterned after the Venetian Banco della Piazza di Rialto of 1587.

${ }^{33}$ Rousseau and Sylla (2005) show that the same period in the US history of financial development was characterized by finance-led growth, suggesting that these 'intimate' relationships between banks and state governments were conducive to economic growth.
} 


\subsection{Japan, Korea and Taiwan}

The emergence of strong banking systems that supported the remarkable growth of post-war Japan and Taiwan and post-1960's South Korea is well documented in recent literature. It is also widely recognised that the role of government in the early stages of the financial development of these countries was critical (see, for example, World Bank (1993), Amsden (1989), Wade (1989) and Wade (1990)). The banking systems of these countries, which were tightly controlled by their respective governments for at least two decades, if not more, are widely credited with transforming their respective economies into the industrialised nations that they are today (Patrick and Park 1994). Government interventions took many forms, including partial or total ownership of major banks, extensive government involvement in credit allocation, interest rate controls etc. $^{34}$

What is perhaps less widely emphasised in the literature on East Asian financial development is the fact that certain forms of government interventions - such as restrictions on entry - amounted to restrictions on competition, which helped tightly controlled banks to remain profitable. This also enabled governments to use them as cheap sources of finance not so much for themselves but for their priority industrial sectors, which were central in their industrialisation strategies. Moreover, restrictions on competition did not result in a reduced volume of loans because of the parallel existence of interest rate controls, which effectively guaranteed gross profit margins for banks (see Kitagawa and Kurosawa (1994)). In such a set-up banks could increase profit by increasing volume, which encouraged financial development by enhancing

\footnotetext{
${ }^{34}$ Teranishi (1994) outlines the emergence of the Japan's heavily regulated financial system during the high growth period (1956-70) and analyses the ways in which it contributed to economic growth, focusing on the realization of dynamic scale economies. Park and Kim (1994) document the extensive controls of the Korean government over commercial banks, which for many years included the determination of deposit and lending rates at practically all financial institutions (p. 191). Shea (1994) outlines the emergence of the Taiwanese system, which has been dominated by government owned and managed banks.
} 
competition among existing banks. ${ }^{35}$

\subsection{Counter-examples}

It may be argued that by focusing our analysis on Europe and Asia, which contained predominantly successful cases of financial development through government involvement, we are biasing our conclusions. This may be because in other parts of the world government involvement in the financial system has been detrimental to financial development. Such counter-examples may be found in Central and Latin America, as well as in Sub-Saharan Africa, where financial development has stagnated notwithstanding (or perhaps because of) government involvement. One potentially good counter-example is that of Mexico, where throughout the 19th and 20th century, there has been little banking system development, especially if this is measured by the ratio of private credit to GDP. However, careful examination of the conditions in the Mexican financial system suggests that it is not a valid counter-example to our argument. This is because, in accordance to some of the most authoritative analyses, Mexico has been a classic case of weak property rights (e.g. Haber, Razo and Maurer (2003, Ch. 4)). ${ }^{36}$ Our argument does not apply to cases with weak property rights. We see adequate property rights protection as a necessary condition for financial development to occur (through privately owned banks or markets) ${ }^{37}$ but not a sufficient

\footnotetext{
${ }^{35}$ See Demetriades and Luintel (2001) for evidence of the positive role played by governmentimposed financial restraints on the development of the South Korean banking system. Their theoretical analysis of a cartelised banking system explains how a positive association between financial development, the degree of state control over the banking system and mild repression of lending rates can arise.

${ }^{36}$ In Mexico banking development was stifled because a succession of authoritarian governments with a tendency to expropriate, frequently in subtle ways, offered privileges to the banking elite, such as limiting entry, to ensure their continued cooperation (Haber forthcoming).

${ }^{37}$ Without secure property rights, private banking may fail to take off, especially if prudential regulation is weak because depositors may not trust banks, where opportunistic behaviour is not contained. In these circumstances, governments can still play a role in kick-starting financial devel-
} 
one. Our argument is that once sufficiently secure property rights are in place, the government can play an important role in kick-starting financial development through careful interventions.

\section{Conclusions}

This paper provides evidence from historical sources which suggests that the emergence of London and Amsterdam's financial markets can be ascribed to the rise of large trading monopolies with close links to government. These monopolies were responsible for the main financial innovations that gave rise to the emergence of trading in shares. We argue that London and Amsterdam were not special cases in the sense that government has played a critical role in the emergence of financial systems worldwide.

An important feature of the trading monopolies in London and Amsterdam was their broad based ownership which enabled them to mobilise saving from a wide class of investors. The monopoly position seems to have been critical in enabling them to issue securities with attractive risk-return characteristics, which, as a result, were easily tradable, giving rise to a secondary market. In this context, the establishment of banking monopolies with close links to government seems to have been a natural consequence and it is the prevalence of such monopolies that facilitated the emergence of banking systems worldwide.

The evidence presented here also suggests that the London market emerged well before the strengthening of private property rights that followed the Glorious Revolution of 1688 in England. While this finding does not suggest that property rights are not necessary for the emergence of financial market - they may have been secure before 1688 - it does suggest that ascribing the emergence of the London stock market

opment through government owned banks (Andrianova, Demetriades and Shortland 2008). 
to the reforms of 1688 is incorrect. ${ }^{38}$

Could the models of Amsterdam and London be mimicked by countries that remain financially underdeveloped today? The VOC and East India models suggest that careful exploitation of a valuable natural resource - trading routes in those casesmay help to mobilise saving and improve public finances, both of which may be critical to kick start financial development. Whether this avenue is open to low income economies in a modern context is an important question for policy makers which warrants further investigation, both theoretically and empirically. A tentative prediction of our analysis is that countries endowed with valuable tradable resources, such as oil or gas, which also have sufficiently secure private property rights may be able to kick start their financial systems through careful government intervention. Specifically, inviting bids for monopoly licenses for the exploitation of such resources from domestic investors could deliver benefits for both the government and domestic private sectors, as long as ownership of such monopolies is broad based. This is an important caveat. If this vital ingredient of the London and Amsterdam models is neglected, the formation of such monopolies would not only fail to mobilise saving but it could also result in the creation of new economic oligarchies that are likely to stifle financial development for a long time.

As a final remark, the analysis of the emergence of financial markets in London and Amsterdam and the emergence of banking in Hong Kong, can also be related to recent work by North, Wallis and Weingast (2006) [henceforth, NWW]. The key concepts in NWW are the 'natural state' and the 'open access state'. The natural state is characterised by limited access in the sense that it provides order by "using the political system to limit economic entry to create rents, and then using the rents to stabilize the political system and limit violence". The most important mechanism of a limited access order is to contain violence and to provide social stability and

\footnotetext{
${ }^{38}$ Haber et al. (2003) argue that selective enforcement of property rights by the government can serve as a substitute for uniform property rights enforcement (provided by the government as a public good) and could deliver economic growth even in the presence of political instability.
} 
order. Such system, however, fails to achieve sustained economic growth: according to NWW, most contemporary countries, including all developing countries, are natural states. In contrast, an open access state, as the name suggests, is characterised by "open access and entry into economic and political organizations". Social order in such society is sustained by competition rather than rent-creation. Moreover, an open access state is able to achieve sustained rates of economic growth and development. According to NWW, only about two dozens contemporary countries, such as the US, the major EU countries, and Japan etc., are open access societies.

Re-interpreting our work within the NWW framework, our treatment of the political economy of initial financial development in pre-industrial revolution era can be regarded as a successful development being achieved in a 'natural state', which lays the foundations for later transformation of the natural state into an open access society. We show that historically successful initial financial development in the case of London, Amsterdam and Hong Kong started with political protection and monopoly (or oligopoly), and that part of the reason for political protection was to limit competition in order to create rents. In these examples, rent-creation by means of political power has played an important positive role in trade and financial development. Essentially, as we argued above, without this protection or limitation to access, large scale trading and large scale financial development, which provided a base for later industrial revolution, may have never happened. We conjecture that only when financial development has passed a certain threshold does it become beneficial to lower entry barriers to allow for more competition, i.e. open access. Our analysis therefore suggests that certain types of 'natural states' may be useful at earlier stages of development since they provide necessary conditions for achieving open access society later. To this extent, our discussion sheds lights on conditions of initial financial development which determines later transformation from the natural state to the open access society. Without this initial financial development, countries even with plenty of wealth and advanced technology (technologies comparable to those developed during the industrial revolution), e.g. a country such as China in the 1200s 
or in the 1500 s and the $1600 \mathrm{~s}$, were not able to further develop and were not able to transform from natural state to open access society.

\section{References}

Acemoglu, Daron, Simon Johnson, and James A. Robinson, "Institutions as a Fundamental Cause of Long-Run Growth," in Philippe Aghion and Steven N. Durlauf, eds., Handbook of Economic Growth, Volume 1A, Elsevier, North Holland, 2005.

__ _ _ and _ _ , "The Rise of Europe: Atlantic Trade, Institutional Change and Economic Growth," American Economic Review, June 2005, 95, 546-579.

Amsden, Alice H., Asia's Next Giant: South Korea and Late Industrialization, Oxford University Press, 1989.

Andrianova, Svetlana, Panicos O. Demetriades, and Anja Shortland, "Government Ownership of Banks, Institutions, and Financial Development," Journal of Development Economics, 2008, 85, 218-52.

Barbour, Violet, Capitalism in Amsterdam in the Seventeenth Century, Baltimore: The Johns Hopkins Press, 1950.

Carlos, Ann M., Jennifer Key, and Jill L. Dupree, "Learning and the Creation of Stock Market Institutions: Evidence from the Royal African and Hudson's Bay Companies, 1670-1700," The Journal of Economic History, 1998, 58 (2), $318-44$.

Carruthers, Bruce G., City of Capital: Politics and Markets in the English Financial Revolution, Princeton, New Jersey: Princeton University Press, 1996. 
de Vries, Jan and Ad van der Woude, The First Modern Economy: Success, Failure, and Perseverance of the Dutch Economy, 1500-1815, Cambridge: Cambridge University Press, 1997.

Dehing, Pit and Marjolein 't Hart, "Linking the fortunes: currency and banking 1550-1800," in Marjolein 't Hart, Joost Jonker, and Jan Luiten va Zanden, eds., A Financial History of the Netherlands, Cambridge: Cambridge University Press, 1997.

Demetriades, Panicos O. and Kul Luintel, "Financial Restraints in the South Korean Miracle," Journal of Development Economics, 2001, 64, 459-479.

and Svetlana Andrianova, "Finance and Growth: What We Know And What We Need to Know," in C.A.E. Goodhart, ed., Financial Development and Growth: Explaining the Links, Palgrave Macmillan, 2004.

Dickson, P. G. M., The Financial Revolution in England, London: Macmillan, 1967.

Fratianni, Michele and Franco Spinelli, "Did Genoa and Venice Kick a Financial Revolution in the Quattrocento?," 2005. Mimeo.

Gelderblom, Oscar and Joost Jonker, "Completing a Financial Revolution: The Finance of the Dutch East India Trade and the Rise of the Amsterdam Capital Market, 1595-1612," The Journal of Economic History, 2004, 64 (3), 641-72.

Gilbert, William, Renaissance and Reformation, Lawrence, KS: Carrie, 1998.

Goodhart, Charles A. E., The Evolution of Central Banks, MIT Press, 1988.

Haber, Stephen, "Why Institutions Matter: Banking and Economic Growth in Mexico, 1821-2004," in Christopher Welna, ed., Reforming the State in Mexico, University of Notre Dame Press, forthcoming. 
, Armando Razo, and Noel Maurer, The Politics of Property Rights: Political Instability, Credible Commitments, and Economic Growth in Mexico, 18761929, Cambridge: Cambridge University Press, 2003.

Holmes, Geoffrey, The Making of a Great Power, London: Longman, 1993.

Israel, Jonathan I., Dutch Primacy in World Trade, 1585-1740, Oxford: Clarendon Press, 1989.

Ji, Zhaojin, A History of Modern Shanghai Banking, Armonk, N. Y.: M. E. Sharpe, 2003.

King, Frank H. H., Eastern Banking: Essays in the History of the Hongkong and Shanghai Banking Corporation, Athlone Press, 1983.

— - The History of the Hongkong and Shanghai Banking Corporation, Cambridge: Cambridge University Press, 1987. In four volumes.

Kitagawa, Hiroshi and Yoshitaka Kurosawa, "Japan: Development and Structural Change of the Banking System," in Hugh T. Patrick and Yung Chul Park, eds., The Financial Development of Japan, Korea and Taiwan, Oxford University Press, 1994.

Levine, Ross, "More on Finance and Growth: More Finance, More Growth?," Federal Reserve Bank of St. Louis Review, 2003, 85 (4), 31-46.

Neal, Larry, "The Dutch and the English East India Companies Compared: the Evidence from the Stock and Foreign Exchange Markets," in J. D. Tracey, ed., The Rise of Merchant Empires: Long-Distance Trade in the Early Modern World 1350-1750, Cambridge University Press, 1990.

, The Rise of Financial Capitalism: International Capital Markets in the Age of Reason, Cambridge: Cambridge University Press, 1990. 
North, Douglass C. and Barry R. Weingast, "Constitutions and Commitment: The Evolution of Institutions Governing Public Choice in Seventeenth-Century England," The Journal of Economic History, 1989, 49 (4), 803-32.

_ _ John Joseph Wallis, and Barry R. Weingast, "A Conceptual Framework for Interpreting Recorded Human History," 2006. NBER, Working Paper \#12795.

Park, Yung Chul and Dong Won Kim, "Korea: Development and Structural Change of the Banking System," in Hugh T. Patrick and Yung Chul Park, eds., The Financial Development of Japan, Korea and Taiwan, Oxford University Press, 1994.

Patrick, Hugh T. and Yung Chul Park, The Financial Development of Japan, Korea and Taiwan, Oxford University Press, 1994.

Rajan, Raghuram G. and Luigi Zingales, "The Great Reversals: The Politics of Financial Development in the 20th Century," Journal of Financial Economics, 2003, 69 (1), 5-50.

Roseveare, Henry, The Financial Revolution 1660-1760, New York: Longman, 1991.

Rousseau, Peter L., "Historical Perspectives on Financial Development and Economic Growth," 2002. NBER, Working Paper \#9333.

and Richard Sylla, "Emerging Financial Markets and Early US Growth," Explorations in Economic History, 2005, 42, 1-26.

Scott, William Robert, The Constitution and Finance of English, Scottish and Irish Joint-Stock Companies to 1720, Cambridge: Cambridge University Press, 1912. 
Shea, Jia-Dong, "Taiwan: Development and Structural Change of the Financial System," in Hugh T. Patrick and Yung Chul Park, eds., The Financial Development of Japan, Korea and Taiwan, Oxford University Press, 1994.

Smith, Adam, Lectures on Justice, Police, Revenue and Arms, Oxford: Clarendon Press, 1763. Edited with introduction and notes by Edwin Cannan (1896).

— An Inquiry into the Nature and Causes of the Wealth of Nations, Oxford: Clarendon Press, 1776. Eds. R. H. Campbell, A. S. Skinner and W. B. Todd. Reprinted in two volumes (1976).

Smith, Alan R. G., The Emergence of a Nation State: the Commonwealth of England 1529-1660, London: Longman, 1984.

Smith, C. F., "The Early History of the London Stock Exchange," American Economic Review, 1929, 19 (2), 206-16.

Stasavage, David, "Credible Commitment in Early Modern Europe: North and Weingast Revisited," Journal of Law, Economics and Organization, 2002, 18 (1), 155-186.

Steensgaard, Niels, "The Dutch East India Company as an institutional innovation," in Maurice Aymard, ed., Dutch Capitalism and World Capitalism, Cambridge: Cambridge University Press, 1982.

Stiglitz, Joseph E., "The Role of the State in Financial Markets," Proceedings of the World Bank Annual Conference on Development Economics, 1993.

Sylla, Richard, John B. Legler, and John J. Wallis, "Banks and State Public Finance in the New Republic: The United States, 1790-1860," The Journal of Economic History, 1987, 47 (2), 391-403.

Teranishi, Juro, "Japan: Development and Structural Change of the Financial System," in Hugh T. Patrick and Yung Chul Park, eds., The Financial Development of Japan, Korea and Taiwan, Oxford University Press, 1994. 
Wade, Robert, "What Can Economies Learn from East Asian Success?," Annals of the American Academy of Political Science, 1989, 505, 68-79.

— Governing the Market: Economic Theory and the Role of the Government in East Asian Industrialization, Princeton University Press, 1990.

World Bank, East Asian Miracle, Oxford University Press, 1993. 